\title{
ANALISIS DATA SUB BOTTOM PROFILER TERINTEGRASI UNTUK IDENTIFIKASI SEDIMEN (STUDI KASUS: ALUR PELAYARAN TIMUR SURABAYA)
}

\author{
Khomsin ${ }^{1}$, Danar Guruh Pratomo르. M. Dwiki Amirullah ${ }^{3}$ \\ 1,2,3 Departemen Teknik Geomatika FTSLK-ITS, Kampus ITS Sukolilo, Surabaya, 60111 \\ e-mail: ${ }^{1}$ khomsin@geodesy.its.ac.id, ${ }^{2}$ guruh@geodesy.its.ac.id, ${ }^{3}$ wikiamirullah@gmail.com
}

\begin{abstract}
Abstrak
Salah satu instrument akustik yang digunakan untuk pengukuran dasar perairan adalah Sub Bottom Profiler. Instrument ini menggunakan sinyal akustik frekuensi rendah yang memiliki kemampuan untuk menembus lapisan dasar laut sampai dengan kedalaman beberapa meter. Tujuan dari survei menggunakan Sub Bottom Profiler yaitu untuk melakukan investigasi dan identifikasi lapisan dasar laut sehingga diperoleh informasi penting yang berhubungan dengan stratigrafi dasar laut. Lokasi penelitian berada pada Alur Pelayaran Timur Surabaya. Data sekunder berupa Raw data Sub bottom profiler, Raw data single beam, serta data pasut dan SVP yang telah diolah. Data tersebut diperoleh dari Distrik Navigasi Kelas 1 Surabaya. Lokasi penelitian merupakan perairan yang digolongkan sebagai perairan dangkal. Hal ini dapat dilihat dari nilai kedalaman yang berkisar antara 2,51- 5,95 m terhadap LWS. Intepretasi kulitatif citra dasar laut menunjukkan adanya pengaruh hue saturation. Semakin terang hue saturation maka sedimen memiliki ukuran partikel besar. Sedimen pada daerah Alur Pelayaran Timur Surabaya didominasi oleh jenis sedimen lumpur berpasir dengan luas area sedimen $93.133 \mathrm{~m}^{2}$ pada area penelitian. Pola refleksi seismik pada konfigurasi data bersifat seragam (parallel) dan relative seragam (subparallel). Ketebalan antara dasar permukaan laut dengan lapisan pertama memiliki sedimen penyusun berupa lumpur berpasir. Volume total ketebalan lapisan sedimen adalah $17.945 .928,40 \mathrm{~m}^{3}$.
\end{abstract}

Kata kunci: Sub bottom, lapisan Sedimen, ketebalan sedimen, lumpur berpasir.

\begin{abstract}
Sub Bottom Profiler is an acoustic instrument used to acquire the information below the seafloor. This instrument uses a low frequency acoustic and is able to penetrate the sediment under the seafloor up to several water in depter. The purpose of the Sub Bottom Profiler survey is to investigate and identify the stratigraphy of the ocean bottom. The research processed the data collected by the Navigation Distric of Surabaya. The site location is in East Surabaya Acces Channel. Which is classified as a shallow water area. The depth ranges from 2.51 in to $5.95 \mathrm{~m}$ with respect to LWS. Side Scan Sonar Interpretation based on the sediment in this area is classified into rock sand, sandy-mud, and mud. Sandy mud is dominated this area with approve modely $93,133 \mathrm{~m}^{2}$ of 276,891 $\mathrm{m}^{2}$ in to area. There are three layers of sediment. The pattern of seismic reflection data are uniform configuration (parallel) and relative uniform (subparallel). The thickness between the base of the sea surface and the first layer has a constituent sediments form the sandy mud. The total volume of the thickness of the layer sediment is $17,945,928.40 \mathrm{~m}^{3}$.
\end{abstract}

Keywords: Sub bottom profiler, Layer of sediment, Thickness of sediment, sandy mud 


\section{PENDAHULUAN}

\section{Latar Belakang}

Survei batimetri adalah proses pemetaan dasar perairan, dimulai dari pengukuran, pengolahan, hingga visualisasi dasar perairan (Poerbandono dan Djunarsjah 2005). Morfologi dasar laut merupakan bagian dari panorama permukaan dasar laut yang berkaitan dengan proses-proses geologi dalam pembentukan dan perkembangannya. Berdasarkan peta batimetri Indonesia, pola batimetri yang berkembang memperlihatkan morfologi dasar laut mengikuti garis pantai dan pola hasil tektonik (Salahuddin, 2001). Informasi mengenai batimetri dan morfologi dasar laut selanjutnya digunakan untuk perencanaan dan pertimbangan dalam menentukan jalur pelayaran yang aman.

Alur Pelayaran Barat Surabaya (APBS) merupakan alur pelayaran yang menghubungkan kapal-kapal yang akan berlabuh di Pelabuhan Tanjung Perak dari Laut Utara Jawa. Sedangkan Alur Pelayaran Timur Surabaya (APTS) merupakan penghubung pelabuhan-pelabuhan di APBS dengan pelabuhan di Jawa Timur antara lain Pelabuhan Pasuruan, Probolinggo, Panarukan, Kalbut, Branta, Kalianget, dan Banyuwangi serta Pelabuhan di wilayah Indonesia bagian Tengah dan Timur. Penetapan APTS sangat penting dikarenakan lalu lintas kapal yang keluar masuk ke Pelabuhan Tanjung Perak sudah sangat padat dan dapat membahayakan keselamatan pelayaran sehingga diperlukan alur pelayaran lain selain APBS (Setyobudi 2017). Selanjutnya, untuk menentukan penetapan APTS ini diperlukan pengukuran dasar perairan.

Pada penelitian ini, data analisa ketebalan sedimen didapatkan dari survei di wilayah Alur Pelayaran Timur Surabaya dengan menggunakan Sub Bottom Profiler innomar SES 2000 light plus. Survei singlebeam ecosounder juga dilakukan untuk menentukan kedalaman secara akurat karena hasil ukuran batimetri menggunakan alat SBP tidak sesuai dengan standar yang dibutuhkan berdasarkan IHO - 2008 atau SNI (Afif 2017). Selanjutnya perlu dilakukan pengolahan data hasil survei Sub Bottom Profiler untuk memperoleh informasi yang dimaksud.

Tujuan dari penelitian ini yaitu menganalisis data dari SBP untuk selanjutnya dilakukan identifikasi ketebalan sedimen. Hasil penelitian ini diharapkan dapat digunakan sebagai acuan dalam pengembangan keamanan wilayah Alur Pelayaran Timur Surabaya.

\section{METODOLOGI PENELITIAN}

\section{Lokasi Penelitian}

Lokasi daerah penelitian berada pada Alur Pelayaran Timur Surabaya secara georafis lokasi penelitian ini terletak pada koordinat 07 17'15.06" LS dan $112^{\circ} 50^{\prime}$ 48.84" BT sampai dengan $077^{\circ} 23^{\prime} 30.98^{\prime \prime}$ " LS dan $112^{\circ}$ $58^{\prime} 03.45^{\prime \prime}$ BT, yang ditunjukkan dalam Gambar 1.

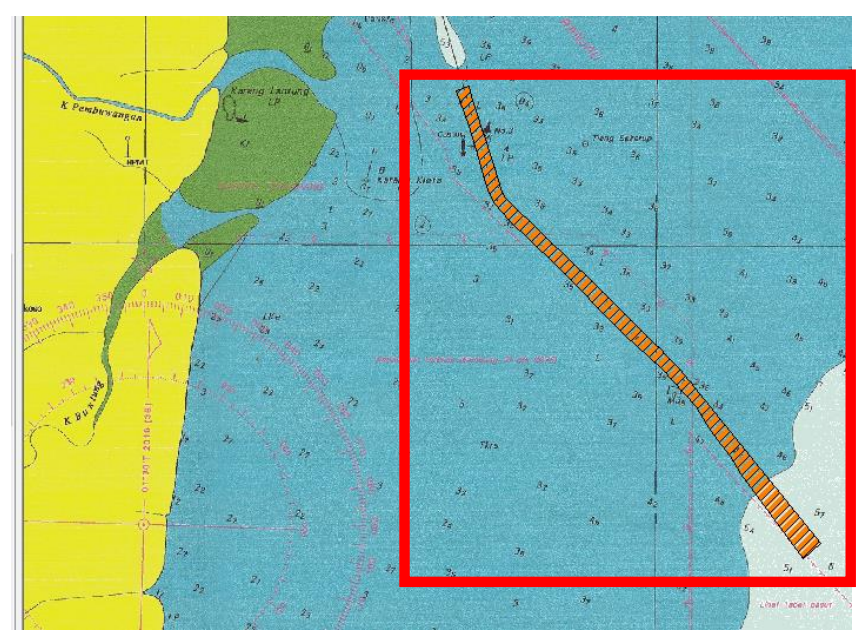

Gambar 1. Lokasi Penelitian Alur Pelayaran Timur Surabaya

\section{Data}

Data yang digunakan adalah data sekunder berbentuk raw data akustik dari instrument Sub Bottom Profiler dengan format SES dari Instrumen Innomar SES-2000 light plus daerah Alur Pelayaran Timur Surabaya tahun 2015. Raw data hasil pemeruman Singlebeam Ecosounder selanjutnya dikoreksi terhadap pasang surut dan data Sound Velocity Profiler daerah Alur Pelayaran Timur Surabaya tahun 2015. Data sampel sedimen pada daerah Alur Pelayaran Timur Surabaya tahun 2015 diambil dengan alat grab sampler.

\section{Diagram Alir Penelitian}

Pengolahan data dilakukan dalam tiga tahap yaitu tahap pengolahan batimetri untuk meenghasilkan topografi dasar laut, pengolahan data side scan sonar untuk menghasilkan citra dasar laut, dan pengolahan data data seismik untuk menghasilkan lapisan ketebalan sedimen. Pengolahan batimetri dimulai dengan koreksi kedalaman. Pada tahap ini kedalaman hasil pemeruman di koreksi dengan data pasang surut perairan survei dan data 
kecepatan suara dalam air (SVP) sehingga didapatkan data kedalaman terkoreksi. Data batimetri terkoreksi selanjutnya di interpolasi untuk mendapatkan kontur kedalaman. Selanjutnya data batimetri di ploting sesuai koordinat yang sudah ada pada peta dasar. Untuk mempercantik tampilan pada peta, dilakukan proses layouting untuk penyempurnaan gambar hasil kontur kedalaman sebelum disajikan sebagai sebuah peta.

Tahapan selanjutnya yaitu memulai pengolahan, data citra dasar laut. Data .SES yang didapatkan dari alat SBP selanjutnya di konvert ke format data .xtf untuk selanjutnya diolah sehingga di dapatkan citra kedalaman side scan sonar dan format data .segy untuk diolah sehingga di dapatkan data ketebalan sedimen. Data .xtf yang sudah di dapatkan selanjutnya dikoreksi secara geometrik untuk menghilangkan blind zone pada nadir dan secara radiometrik untuk memperhalus tampilan citra side scan sonar. Mosaik citra side scan sonar dilakukan untuk mendapatkan visualisasi dari data side scan sonar dan melihat kenampakan permukaan dasar laut yang terekam. Dari kenampakan permukaan dasar laut, dapat dilakukan analisa daerah mana yang memiliki sedimen bertekstur kasar atau halus. Hasil dari mosaik citra selanjutnya dieksport ke format .geotiff dan di lakukan ploting sesuai koordinat yang ada pada peta dasar.

Tahapan terakhir, yaitu melakukan pengolahan data sesismik. Data sesimik yang diolah berasal dari convert .SES yang berupa .sgy. Setelah itu me lakukan geometri untuk mendefinisikan kordinat shot point. Informasi ini sangat penting, sehingga tahapan geometri ini harus dilakukan dengans hati-hati. Setelah itu memasukan memasukkan parameter untuk mendapatkan nilai kedalaman terkoreksi. Parameter yang dimasukkan meliputi nilai Pasang surut dan SVP. Data .sgy yang sudah di dapatkan selanjutnya dikoreksi secara radiometrik untuk memperhalus tampilan $2 \mathrm{~d}$ data seismik pada software pengolahan. Dynamic Range digunakan untuk memperbaiki rentang intensitas cahaya mulai dari shadow tergelap hingga highlight tercerah dan smooting pada data. Interpretasi data digunakan untuk menentukan batas dasar permukaan perairan dan menentukan ketebalan dari lapisan sedimen serta pola refleksinya. Pada penelitian ini dilakukan interpretasi kualitatif, yaitu dengan melakukan penarikan horizon untuk didapatkan kedalaman perairan dan batas pengendapan sedimen. Validasi data dilakukan untuk menentukan tipe sedimen pada ketebalan antar lapisan. Data yang digunakan adalah data sampel grab sehingga hanya ketebalan terluar saja yang diketahui sedimennya. Hal ini disebabkan karena tidak dilakukan pengambilan data sampel coring pada lapangan dikarenakan keterbatasan alat. Setelah semua pengolahan selesai maka dilakukan penggabungan dan plotting hasil dari tiap bagian pengolahan untuk selanjutnya dilakukan pemodelan ketebalan sedimen. Terakhir, analisis ketebalan sedimen dilakukan untuk menganalisis hasil pemodelan ketebalan sedimen pada sepanjang alur sehingga diperoleh informasi ketebalan sedimen antar lapisan sepanjang alur survei.

\section{HASIL DAN PEMBAHASAN}

\section{Topografi Dasar Perairan}

Raw data single beam, data pasang surut dan data sound velocity profiler yang diperoleh melalui kegiatan survei yang dilakukan oleh Distrik Navigasi Surabaya diolah untuk mendapatkan topografi dasar laut. Jumlah Raw data sebanyak 179 data dimana satu data berisi satu jalur survei sehingga total jalur survei yang diolah sebnyak 179 jalur survei. Luas area penelitian yaitu $276.891 \mathrm{~m}^{2}$ dengan total panjang area $10.033,42 \mathrm{~m}$.

Koreksi terhadap nilai kedalaman single beam dilakukan dengan memasukkan parameter sound velocity profiler dan nilai pasut terhadap datum vertikal surut terendah LWS. Nilai batimetri yang telah terkoreksi selanjutnya di interpolasi dan di ploting kedalam peta laut. 


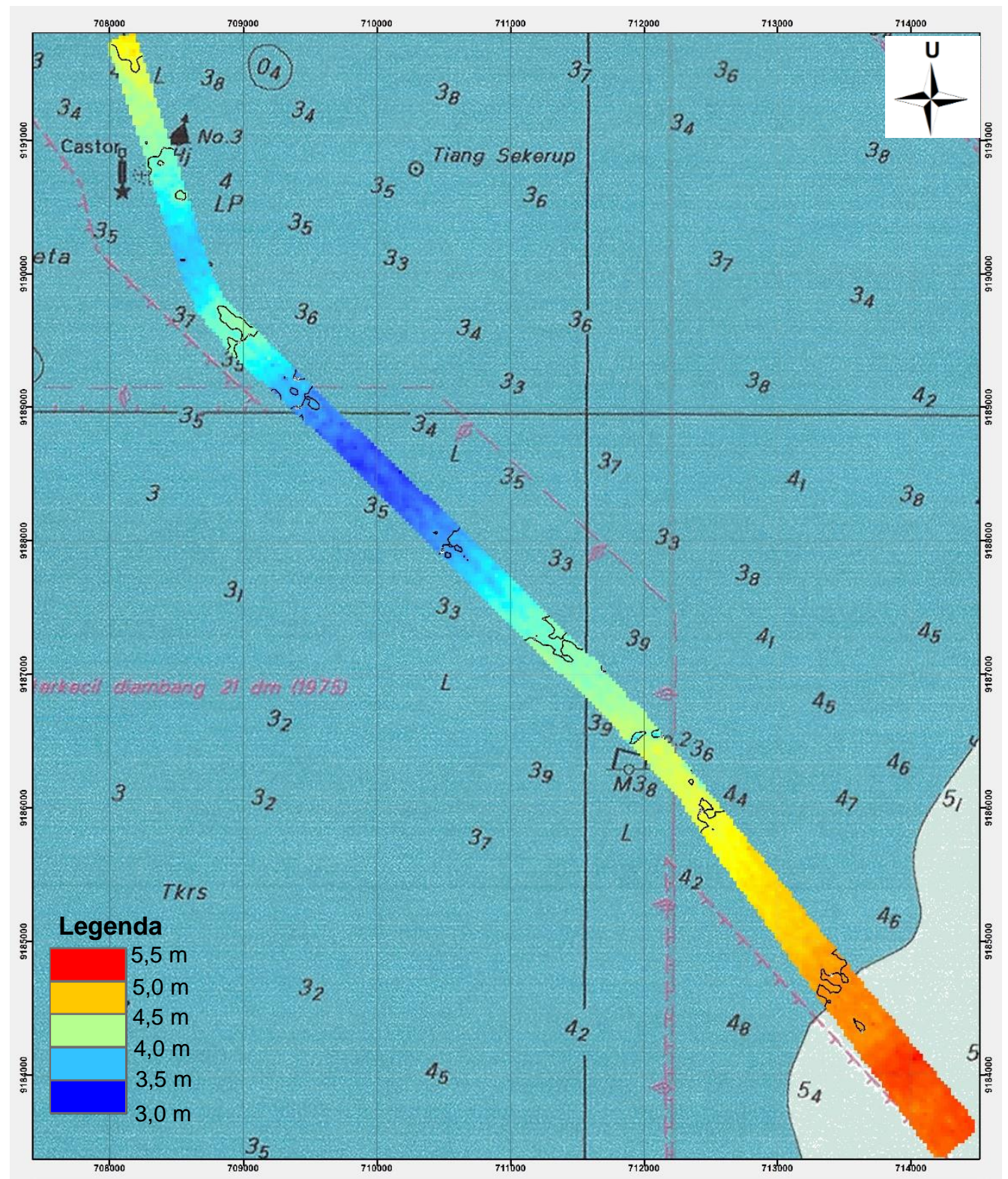

Gambar 2. Hasil Tampilan Data Batimetri Yang Telah Di Ploting.

Kontur peta batimetri Alur Pelayaran Timur Surabaya memiliki kerapatan kontur yang kecil karena variasi nilai kedalaman dari area penelitian. Hal ini dapat dilihat dari nilai kedalaman yang berkisar antara 2,51 sampai 5,95 m terhadap LWS. Sehingga lokasi penelitian dapat dikategorikan sebagai perairan dangkal. Penyajian data disempurnakan dengan melakukan layouting pada peta dengan memasukkan informasi yang terdiri atas nilai posisi dan nilai kedalaman.

\section{Analisis Data Side Scan Sonar}

Area kajian side scan sonar berada pada alur pelayaran timur Surabaya. Data didapatkan dengan mengekstrak file data .SES kebentuk format data
.XTF sehingga dapat diproses citra bawah laut. Jumlah file yang diekstrak berjumlah 179 data. Hasil pemrosesan disajikan pada Gambar 3. Tampilan data citra bawah laut menunjukkan bagian dari sisi kiri (port) dan sisi kanan (starboard), serta pada bagian tengah terdapat blind zone. Penerapan koreksi yang dilakukan berpengaruh terhadap kualitas data side scan sonar yang dihasilkan. Hasil pemrosesan data citra side scan sonar dengan koreksi geometrik meliputi penerapan koreksi bottom tracking, slant range, (Gambar 3b) dan altitude (Gambar 3d) serta koreksi radiometrik meliputi penerapan koreksi Time Varying Gain (Gambar 3c). 

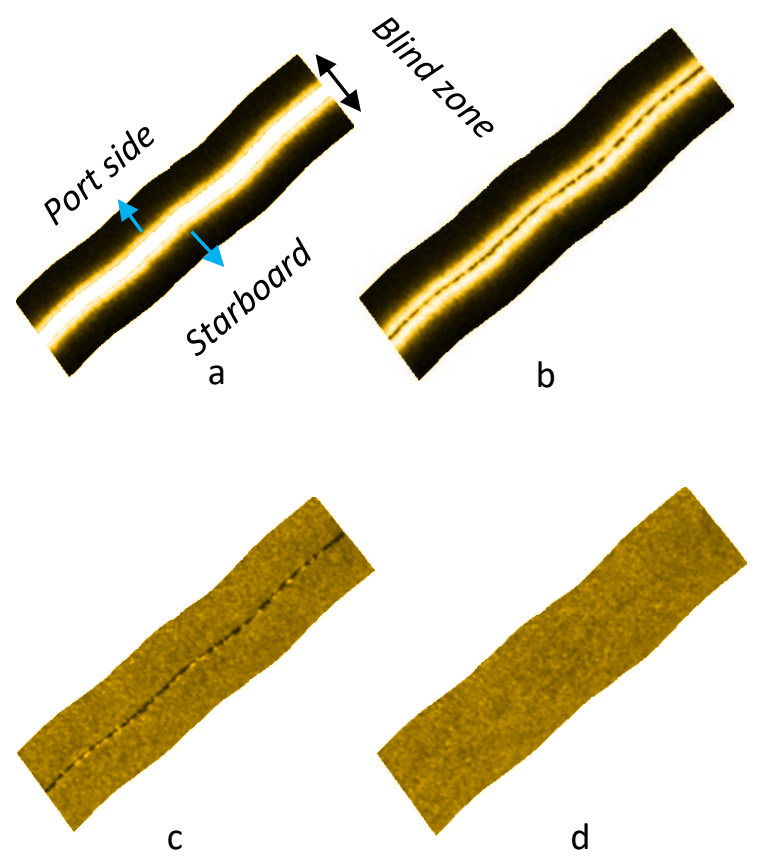

Gambar 3. Hasil Tahapan Pemerosesan Citra Bawah Laut.

Pada gambar 3a, citra side scan sonar tanpa koreksi menunjukkan hasil pencitraan dasar laut setelah mengirimkan gelombang akustik. Sejumlah piksel hanya terdapat pada kedua sisi sebelah nadir area port dan starboard. Pada sisi nadir tidak berisi informasi tentang permukaan dasar laut sehingga disebut daerah blind zone. Piksel nadir sebenarnya menggantikan sisi sebagai fungsi dari kolom air atau ketinggian tranduser alat ke dasarlaut. Hasil penerapan slant range correction pada Gambar 3b dari citra yang disajikan merupakan koreksi terhadap masalah geometris dari pencitraan dasar laut. Koreksi bertujuan untuk menghilangkan bagian blind zone dari citra di setiap baris jalur survei menjadi hilang.

Gambar 3c merupakan penerapan Time Varying Gain (TVG) yang memiliki fungsi untuk mengurangi atenuasi dengan jarak dan efek lainya. Variasi dari hambur balik yang dihasilkan saat sinyal akustik yang diterima lebih rendah daripada yang ditransmisikan mempengaruhi intensitas citra. TVG digunakan sebagai pengoreksi efek tersebut untuk meningkatkan amplifikasi. Koreksi ini termasuk ke dalam bagian koreksi radiometrik yang berpengaruh pada digital number yang ditetapkan pada setiap piksel dalam citra. Setelah dilakukan koreksi radiometrik, terlihat sisa-sisa area blind zone sehingga diperlukan koreksi altitude untuk menghilangkan sisa-sisa blind zone. Hasil koreksi terakhir dapat dilihat pada Gambar 3d.
Mosaik yang dihasilkan melalui penerapan koreksi geometrik dan radiometrik dengan sebuah georeferensi format raster GeoTIFF ditampilkan dalam bentuk system koordinat UTM (Universal Transverse Mercator) Zona $49 \mathrm{~S}$ dengan proyeksi WGS 1984. Dasar dari semua sistem mosaiking adalah melakukan koreksi slant range dan menghilangkan kolom air dari data sonar. Data yang dihasilkan kemudian diplot dengan memperhatikan posisi pada peta berskala dari dasar laut. Mosaik citra side scan sonar dilakukan untuk mendapatkan visualisasi dari data side scan sonar dan melihat kenampakan permukaan dasar laut yang terekam.

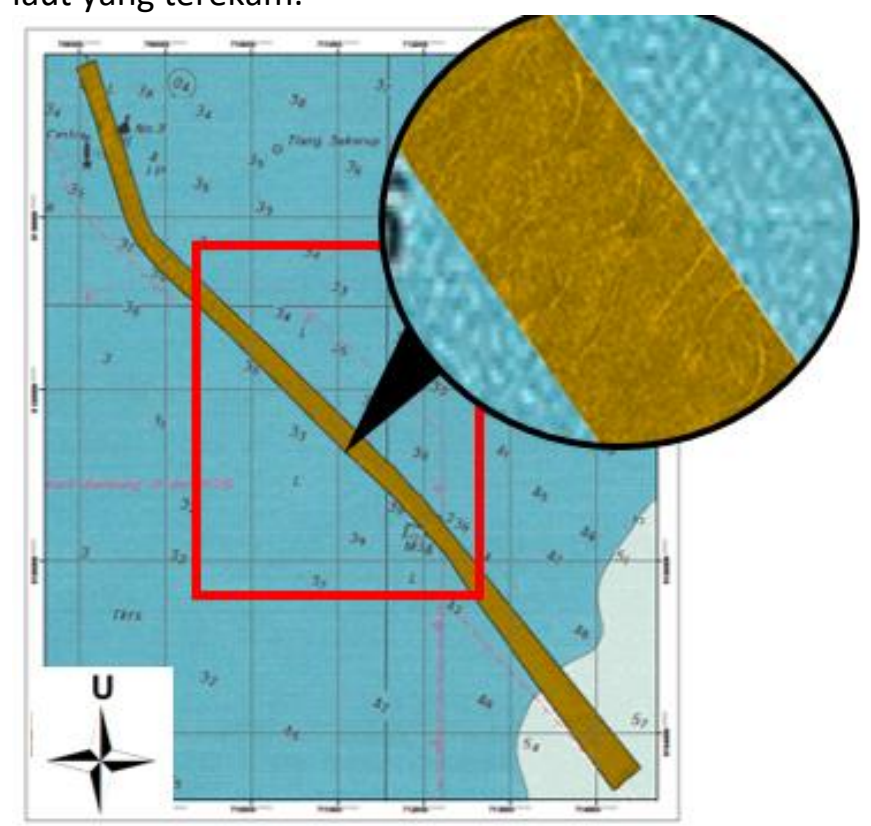

Gambar 4. Hasil Mosaik Citra Bawah Laut Yang Telah Di Ploting Pada Peta Dasar.

Analisis Interpretasi pada citra Side Scan Sonar merupakan kegiatan post processing, interpretasi dilakukan berdasarkan pada bentuk, ukuran dan derajat kehitamaan objek. Berikut adalah sebagian kenampakan visual data perekaman Side Scan Sonar. Secara umum, objek tampak sebagai bentuk sedimentasi materi yang terendap di dasar perairan.

\section{a. Fitur Lumpur}

Fitur lumpur dapat diinterpretasikan dengan bentuk butiran kecil, hue saturation yang gelap, pola dan tekstur halus tanpa adanya shadow. 


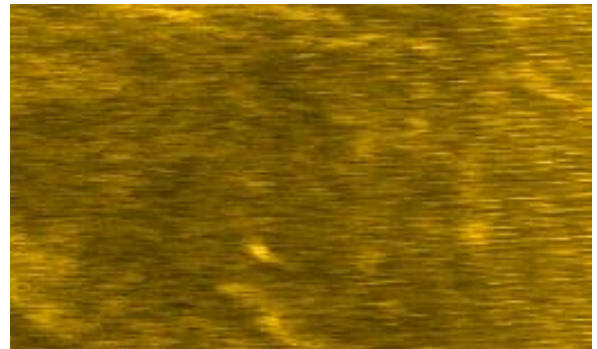

Gambar 5. Fitur Lumpur Pada Citra Side Scan Sonar.

b. Fitur Lumpur Berpasir

Fitur Pasir dapat di interpretasikan dengan butiran kecil, hue saturation sedang, dengan pola dan tekstur halus tanpa adanya shadow.

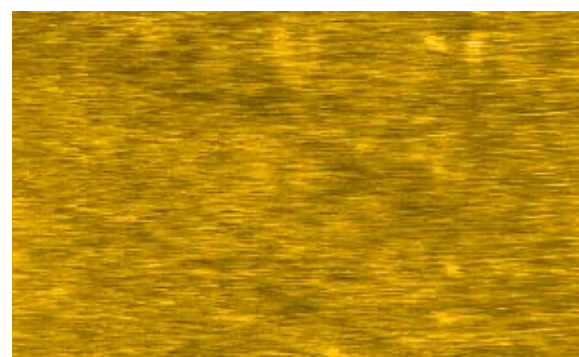

Gambar 6. Fitur Lumpur Berpasir Pada Citra Side Scan Sonar.

\section{c. Fitur Pasir}

Fitur Pasir dapat di interpretasikan dengan butiran kecil, hue saturation yang terang, dengan pola dan tekstur halus tanpa adanya shadow.

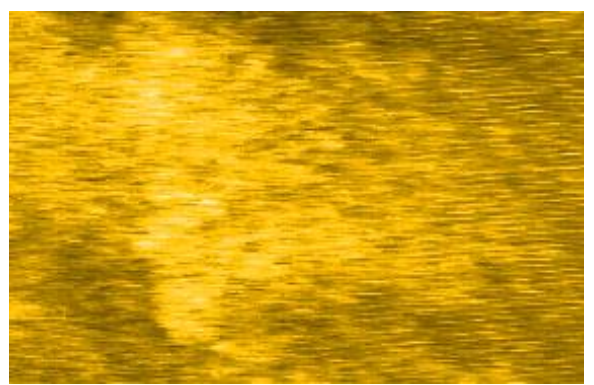

Gambar 7. Fitur Pasir Pada Citra Side Scan Sonar.

\section{d. Fitur Karang dan batuan keras}

Fitur karang atau batuan keras depat di interpretasikan dengan bentuk bongkahan memanjang dengan hue saturation yang terang dengan shadow, pola dan tekstur fitur ini mengelompok besar.

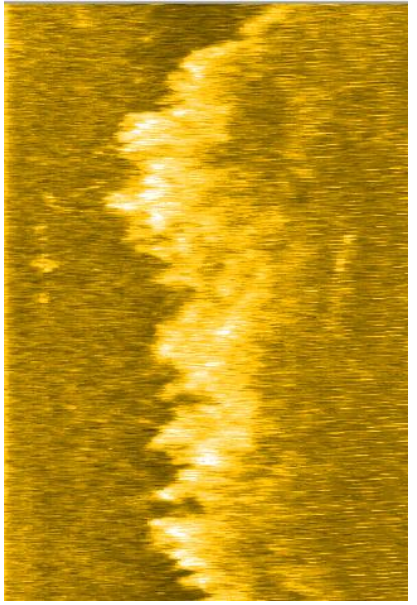

Gambar 8. Fitur Karang Pada Citra Side Scan Sonar.

Dari intepretasi kulitatif citra dasar laut, dapat dilihat bahwa sedimen lumpur memiliki warna yang lebih terang di bandingkan dengan sedimen lumpur berpasir yang memiliki warna lebih gelap. Hal ini di sebabkan data citra side scan yang memiliki amplitudo hambur balik tinggi pada umumnya diwakili oleh gambaran yang lebih terang pada rekaman, sedangkan nilai hambur balik yang rendah ditujukan lebih gelap.

Mosaik citra side scan sonar yang telah diinterpretasi, selanjutnya di hitung luasannya pada setiap area fitur yang di interpretasikan.

Tabel 1 Luasan Fitur Dasar Laut Hasil Interpretasi.

\begin{tabular}{clc}
\hline No & \multicolumn{1}{c}{$\begin{array}{c}\text { Fitur Dasar } \\
\text { Laut }\end{array}$} & Luasan $\left(\mathrm{m}^{2}\right)$ \\
\hline 1 & Lumpur & 78.617 \\
2 & Lumpur Pasir & 93.133 \\
3 & Pasir & 90.836 \\
4 & Batu karang & 14.305 \\
\hline
\end{tabular}

Luasan hasil interpretasi menunjukan sedimen lumpur berpasir lebih mendominan. Selain itu , hasil citra dasar laut juga terlihat kurang jelas dikarenakan frekuensi yang digunakan untuk pengambilan data hanya $250 \mathrm{kH}$.

Pengambilan 10 data sampel lapangan dilakukan untuk memvalidasi hasil interpretasi data. Data sample lapangan dilakukan dengan menggunakan metode grab sampler yang tersebar luas di daerah Alur Pelayaran Timur Surabaya. 
Tabel 2 Koordinat dan jenis sampel lapangan (Disnav 2015)

\begin{tabular}{|c|c|c|c|}
\hline \multirow{2}{*}{ No } & \multicolumn{2}{|c|}{ Koordinat UTM (m) } & \multirow{2}{*}{ Jenis sedimen } \\
\hline & Utara (X) & Timur (y) & \\
\hline 1 & $698.603,98$ & $9.203 .628,05$ & lumpur \\
\hline 2 & $700.753,80$ & $9.203 .364,54$ & lumpur \\
\hline 3 & $700.961,14$ & $9.202 .266,89$ & lumpur pasir \\
\hline 4 & $701.878,39$ & $9.201 .464,42$ & $\begin{array}{l}\text { pasir lumpur } \\
\text { karang }\end{array}$ \\
\hline 5 & $704.660,66$ & $9.205 .474,62$ & lumpur pasir \\
\hline 6 & $708.084,64$ & $9.192 .199,99$ & lumpur pasir \\
\hline 7 & $708.139,82$ & $9.191 .601,64$ & lumpur \\
\hline 8 & $710.857,38$ & $9.202 .493,74$ & lumpur pasir \\
\hline 9 & $714.247,73$ & $9.183 .646,05$ & lumpur pasir \\
\hline 10 & $711.987,95$ & $9.186 .524,70$ & lumpur pasir \\
\hline
\end{tabular}

Hasil sampel lapangan menunjukan bahwa sedimen penyusun dasar laut Alur Pelayaran Timur Surabaya rata rata tersusun dari sedimen lumpur berpasir.

\section{Analisis Data Sub Bottom Profiler}

Sama seperti pengolahan data side scan sonar, dilakukan konversi data dari format data .SES ke format data .SGY. Selanjutnya data dimasukkan bersama parameter data lainnya seperti data pasut dan data SVP kedalam perangkat lunak pengolahan. Penerapan koreksi dilakukan untuk memperjelas tampilan data sehingga ketika dilakukan penarikan horizon bisa . Hasil pemrosesan data SBP meliputi penerapan koreksi bottom tracking dan auto range serta koreksi radiometrik meliputi penerapan koreksi Time Varying Gain. Pada proses awal dilakukan koreksi Auto range dan bottom tracking untuk memperjelas jarak antara kolom air dengan permukaan dasar laut dan menghilangkan rambatan gelombang pada kolom air. Proses Bottom tracking juga menghasilkan garis dasar bawah laut di sepanjang jalur survei. Koreksi TVG dilakukan untuk menyatukan beberapa trace yang spesifik untuk menjadi satu trace dan juga untuk melakukan smooting pada data. Koreksi TVG juga berfungsi untuk memperbaiki kualitas tampilan data.

Proses selanjutnya yaitu memperjelas tampilan data dengan memperbaiki rentang intensitas cahaya mulai dari shadow tergelap hingga tercerah. Proses ini dinamakan dynamic range. Pada proses dynamic range dilakukan dengan mengubah warna tampilan data dan mengubah kerapatan data sehingga perbedaan kontras warna akan terlihat sangat jelas. Hasil dari proses dynamic range bisa dilihat pada.

Berdasarkan teori reflektivitas, kontras warna yang jelas menunjukkan batas ketebalan lapisan sedimennya. Interpretasi data dilakukan dengan membuat garis batas antara kontras warna yang berbeda. Pembuatan batas lapisan dilakukan dengan cara digitizing sesuai bentuk garis lekukan lapisan dasar laut.

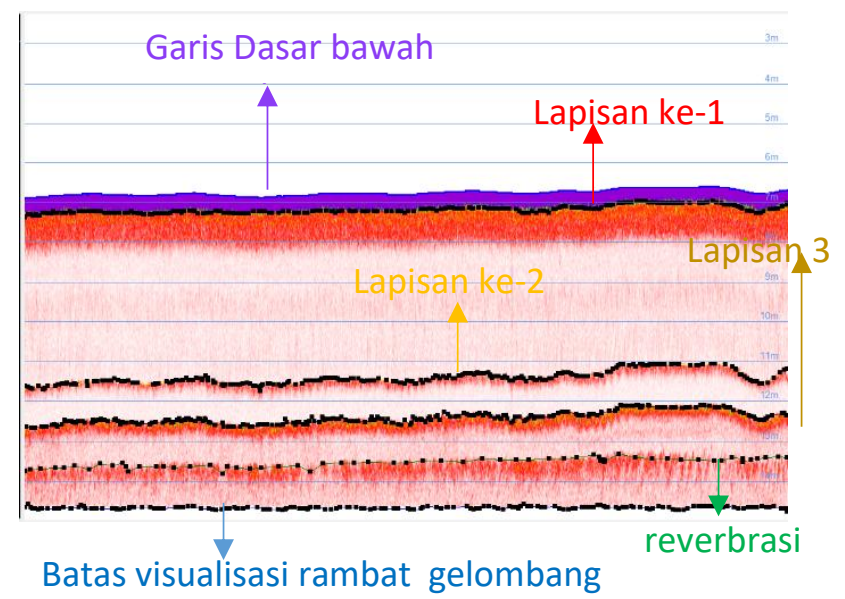

Gambar 9. Hasil Digitasi Batas Lapisan Pada Data SBP

Selain itu untuk memperjelas batas poligon, dapat dilakukan dengan dengan memberikan warna pada batas antar lapisan . Namun pewarnaan area ketebalan hanya bisa dilakukan maksimal 3 batas lapisan. Untuk mengamati hasil digitasi dan pewarnaan area bisa dilakukan dengan diagram fence. Diagram fence adalah diagram gambaran penampang setiap baris dari data SBP. Berikut hasil dari pewarnaan area ketebalan sedimen dan diagaram fence.

Hasil bottom tracking dan digitasi lapisan dasar laut selanjutnya disimpan dalam bentuk file .xyz yang selanjutnya dilakukan proses interpratasi data. Interpretasi dilakukan dengan mengamati pola refleksi seismik pada gambar penampang 
lapisan. Untuk mengetahui pola refleksi seismik, dilakukan filtering band pass. Dari hasil filtering band pass, diketahui bahwa pola refleksi seismik pada konfigurasi ini bersifat seragam (parallel) sampai relatif seragam (subparallel). Hal ini di tujukan dengan pola refleksi yang memiliki amplitude yang sejajar, kontinuitas yang seragam, serta adanya cekungan dan time separation yang setabil. Tingkatan variasi lateralnya menunjukkan tingkatan perubahan dalam kecepatan pengendapan lokal dan kandungan litologinya. Adanya kesamaan pola refleksi pada lapisan pertama hingga lapisan ke tiga membuktikan bahwa sedimen diantara lapisan tersebut memiliki pola yang sama.

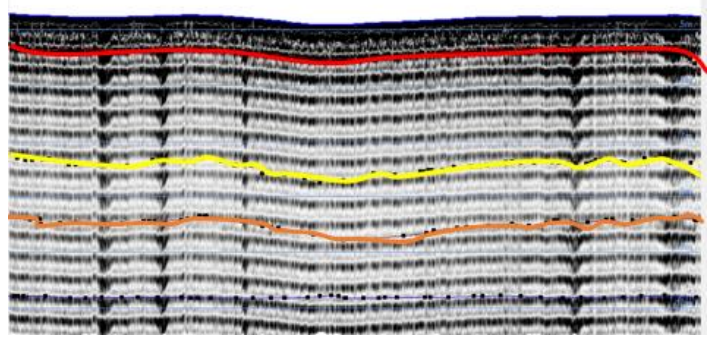

Gambar 10. Hasil Filtering Band Pass.

Setelah itu, dilakukan pemodelan 3 dimensi dari semua lajur yang telah di gitasi tiap lapisannya untuk mengetahui bentuk ketebalan dari sedimen. Hasil sampel area pemodelan antar lapisan ditunjukan oleh Gambar 17.

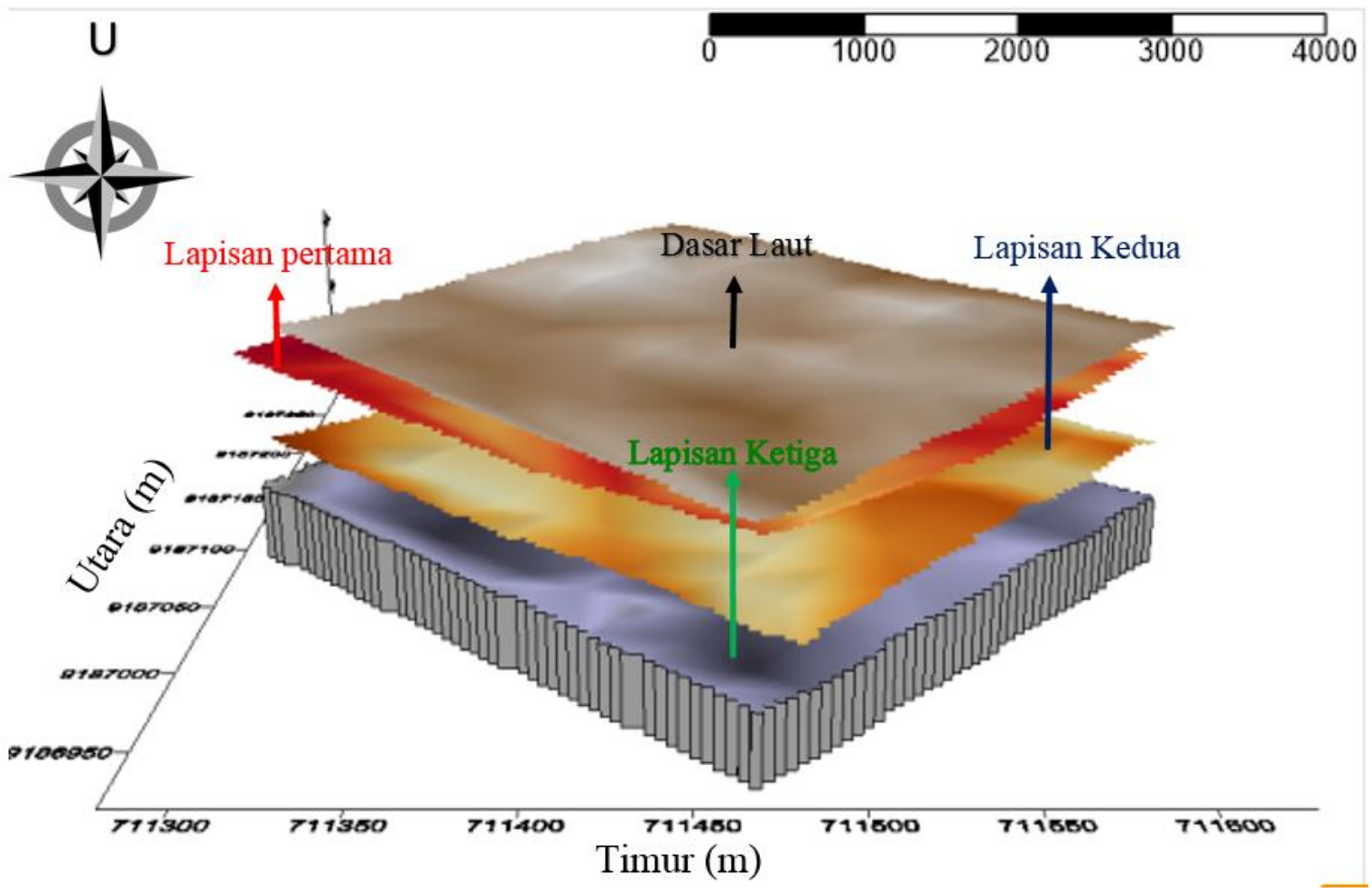

Gambar 11. Hasil Sampel Pemodelan Ketebalan Sedimen Antar Lapisan.

Untuk mengetahui hasil akhir dari pemodelan antar lapisan, dilakukan pemodelan seluruh data dan penggabungan seluruh lapisan. Hal ini dilakukan ntuk melihat visualisasi tiga dimensi secara menyeluruh.

Pemodelan 3 dimensi dilakukan antara data bottom tracking dasar laut dengan lapisan sedimen pertama, antara lapisan pertama dan lapisan kedua, serta antara lapisan kedua dengan lapisan ketiga. Pemodelan 3 dimensi dilakukan dengan metode nearest neighbor.
Untuk mengetahui volume ketebalan sedimen, dilakukan perhitungan volume dengan metode composite. Perhitungan volume dan ketebalan sedimen dilakukan antara permukaan dasar laut dengan lapisan pertama, lapisan pertama dengan lapisan kedua, lapisan kedua dengan lapisan ketiga, serta lapisan ketiga dengan batas visualisasi rambat gelombang. 
Tabel 3. Volume Ketebalan Sedimen Antar Lapisan

\begin{tabular}{|c|c|c|c|}
\hline $\begin{array}{c}\text { No } \\
\text { ketebalan }\end{array}$ & $\begin{array}{c}\text { Batas } \\
\text { Ketebalan } \\
\text { Lapisan }\end{array}$ & $\begin{array}{c}\text { Nilai } \\
\text { Ketebalan } \\
\text { lapisan (m) }\end{array}$ & Volume $\left(\mathrm{m}^{3}\right)$ \\
\hline 1 & $\begin{array}{l}\text { Dasar } \\
\text { Permukaan } \\
\text { dengan } \\
\text { lapisan } \\
\text { pertama }\end{array}$ & 0,70 & $1.638 .618,46$ \\
\hline 2 & $\begin{array}{l}\text { Lapisan } \\
\text { Pertama } \\
\text { dengan } \\
\text { lapisan kedua }\end{array}$ & 3,78 & $8.009 .815,18$ \\
\hline 3 & $\begin{array}{l}\text { Lapisan kedua } \\
\text { dengan } \\
\text { lapisan Ketiga }\end{array}$ & 1,07 & $2.665 .328,73$ \\
\hline 4 & $\begin{array}{l}\text { Lapisan Ketiga } \\
\text { dengan batas } \\
\text { rambat } \\
\text { gelombang }\end{array}$ & 1,62 & $5.632 .166,03$ \\
\hline
\end{tabular}

Untuk mengetahui sedimen penyusun pada masing-masing ketebalan lapisan, dilakukan pengambilan sample sedimen dan interpretasi ketebalan. Sampel sedimen dari lapangan yang diambil hanya bagian atas dasar permukaan laut dengan metode grab sehingga ketebalan sedimen yang diketahui sedimen penyusunnya hanya sedimen yang berada dilapisan antara dasar permukaan laut dengan lapisan pertama. Selain itu hasil interpretasi citra side scan sonar juga menunjukan bahwa sebagian besar dasar permukaan didominasi oleh sedimen lumpur berpasir. Pengambilan sample hingga lapisan terbawah dengan metode coring tidak dilakukan ketika survei daerah Alur Pelayaran Timur Surabaya dikarenakan keterbatasan alat untuk melakukan metode coring tersebut.

\section{KESIMPULAN}

Kegiatan penelitian analisis data Sub Bottom Profiler untuk identifikasi ketebalan sedimen menghasilkan kesimpulan sebagai berikut:

1. Lokasi penelitian merupakan perairan yang digolongkan sebagai perairan dangkal. Hal ini dapat dilihat dari nilai kedalaman yang berkisar antara 2,51- 5,95 m terhadap LWS.

2. Intepretasi kulitatif citra dasar laut menunjukkan adanya pengaruh hue saturation. Semakin terang hue saturation maka sedimen memiliki ukuran partikel besar. Dimana urutan hue saturation sedimen dari terang kegelap yaitu batu karang, pasir, lumpur berpasir, dan lumpur. Sedimen pada daerah Alur Pelayaran Timur Surabaya didominasi oleh jenis sedimen lumpur berpasir dengan luas area sedimen $93.133 \mathrm{~m}^{2}$ pada area penelitian. Luas total area sedimen pada area penelitian yaitu $276.891 \mathrm{~m}^{2}$

3. Terdapat tiga lapisan sedimen. Pola refleksi seismik pada konfigurasi data bersifat seragam (parallel) dan relatif seragam (subparallel). Ketebalan antara dasar permukaan laut dengan lapisan pertama memiliki sedimen penyusun berupa lumpur berpasir. Nilai volume ketebalan lapisan sedimen yang paling besar terdapat antara lapisan pertama dan kedua yaitu sebesar $8.009 .815,18 \mathrm{~m}^{3}$. Volume total ketebalan lapisan sedimen $17.945 .928,40 \mathrm{~m}^{3}$.

\section{UCAPAN TERIMA KASIH}

Penulis mengucapkan terimakasih kepada Distrik Navigasi Kelas 1 Surabaya sebagai penyedia data dalam penelitian kali ini.

\section{DAFTAR PUSTAKA}

Afif, M. 2017. “Analisis Ketelitian Data Sub Bottom Profilers Untuk Pengukuran Kedalaman Permukaan Dasar Laut". Yogyakarta: Universitas Gajah Mada.

Disnav. 2015."Laporan Akhir Survei Hidrografi dan Pembuatan Peta Batimetri APBS, APTS, dan Kalianget". Surabaya: KEMENHUBLA DISNAV Kelas 1.

Poerbandono, \& Djunarsjah. 2005. "Survei Hidrografi". Bandung: Refika Aditama.

Salahuddin, M., Lubis, S., Makmur, A., Astjario, P. 2001. "Pangkalan data Geologi dan Geofisika Kelautan di Wilayah Perairan Indonesia". Bandung: Pusat Pengembangan Geologi Kelautan.

Setyobudi, Hari, interview by Humas Ditjen Hubla. 2017. "KEMENHUB Integrasikan 2 (Dua) Alur Pelayaran Surabaya" Dirjen Hubungan Laut, (April). 